\title{
Analysis of Bacterial Community Associated with Aaptos sp. from Rote and Seribu Islands
}

\author{
EKOWATI CHASANAH ${ }^{1 *}$, GINTUNG PATANTIS ${ }^{1}$, ARIYANTI SUHITA DEWI ${ }^{1}$, ENDAR \\ MARRASKURANTO ${ }^{1}$, HEDI INDRA JANUAR ${ }^{1}$, STELLA $^{2}$, SUSAN SOKA ${ }^{2}$, AND YOGIARA ${ }^{2}$
}

\author{
${ }^{1}$ Research and Development Center for Marine and Fisheries Product Processing and Biotechnology, \\ Jalan KS Tubun, Petamburan 6, Jakarta, Indonesia; \\ ${ }^{2}$ Faculty of Biotechnology, Universitas Katolik Atmajaya, Jalan Jenderal Sudirman 51, \\ Jakarta 12930, Indonesia
}

\begin{abstract}
Aaptos sp. is a marine sponge that could produce bioactive compounds such as aaptamin, aaptosin, and isoaaptamin which have activities as antitumor, antimicrobial, and antiviral. Community of bacteria associated with the sponge might correlate with production of those bioactive compounds and be affected by water environment where the sponge grow. The presence of anthropogenic stressor such as pollutans might become a burden to the waters where the biota grown and could affect the microbial biodiversity in the sponge and its active metabolite produced. The objective of this research was to analyze bacterial community associated with Aaptos sp. from Rote Island and Seribu Islands, using T-RFLP method. The results showed that bacterial community associated with Aaptos sp. from both sampling sites shared $40.81 \%$ similarity in which they were dominated by the same bacteria class of Actinobacteria, Flavobacteria, $\alpha$-proteobacteria, $\delta$-proteobacteria, and $\gamma$-proteobacteria. The bacteria collected from Rote island were more highly distributed and diverse than those from Seribu Islands. A total of 23 classes of microorganism were identified in Rote Island waters, while in Seribu Islands was 14 classes of microorganism. The presence of Actinobacteria and Proteobacteria in Aaptos sp., is allegedly involved in the production of secondary metabolites.
\end{abstract}

Key words: Aaptos sp., microbial diversity, Rote Island, Seribu Islands, T-RFLP

Aaptos sp. merupakan spons laut yang dapat memproduksi senyawa bioaktif seperti aaptamin, aaptosin, dan isoaaptamin yang memiliki aktivitas sebagai antitumor, antimikrobial, dan antiviral. Komunitas bakteri yang berasosiasi dengan spons tersebut kemungkinan berkorelasi dengan produksi komponen bioaktif dan akan dipengaruhi oleh perairan dimana spons tumbuh. Adanya stresor yang disebabkan oleh manusia seperti polutan akan menambah beban perairan ditempat biota tumbuh yang dapat mempengaruhi keragaman mikroba dalam spons dan metabolit aktif yang diproduksi. Tujuan penelitian ini adalah menganalisa komunitas bakteri yang berasosiasi dengan Aaptos sp. dari perairan Pulau Rote dan Kepulauan Seribu, menggunakan metoda T-RFLP. Hasil penelitian menunjukkan bahwa komunitas bakteri yang berasosiasi dengan Aaptos sp. dari kedua daerah sampling memiliki kesamaan 40,81\%, yang didominasi oleh kelas bakteri yang sama yaitu kelas Actinobacteria, Flavobacteria, $\alpha$-proteobacteria, $\delta$-proteobacteria, dan $\gamma$-proteobacteria. Bakteri dari spons yang dikoleksi dari Pulau Rote lebih terdistribusi dan lebih beragam dibanding yang dari spons yang dikoleksi dari kepulauan Seribu. Secara total ada 23 kelas mikroorganisme sebagian besar bakteri yang diidentifikasi ada di spons dari Pulau Rote, sedangkan spons dari Kepulauan Seribu terdapat 14 kelas. Keberadaan Actinobacteria dan Proteobacteria dalam Aaptos sp., diduga berhubungan dengan produksi metabolit sekunder.

Kata kunci : Aaptos sp., Kepulauan Seribu, keragaman bakteri, Pulau Rote, T-RFLP

Aaptos sp., one of marine sponges that can be found abundantly in Indonesian waters, has been reported to produce bioactive metabolite against tumor, pathogenic microbes, and Herpes Simplex Virus type I (HSV-1) (Coutinho et al. 2002). It was detected that the compounds produced were alkaloids, e.g aaptamin, aaptosin and isoaaptamine; the latter compound showed potent activity against Human Immunodeficiency Virus type I (HIV-1) (Gul et al. 2006). Aaptos sp. was also been reported to produce

*Corresponding author; Phone: 62-21-53650157, Fax: +6221-53650158,Email: ekowatichasanah@gmail.com sterol compounds (Rachmat and Muniarsih 2001), and other novel aaptamine alkaloids possesing various biological activities, including cytotoxic against murine lymphoma L5178Y cell line, antiviral, antimicrobial, antifungal, antiparasitic, $\alpha$-adrenergic antagonistic, radical scavenging, and antifouling activity (Pham etal. 2013).

Sponge such as Aaptos sp. is very rich in microorganism including bacteria associated within their body. About $40 \%$ of sponge body is bacteria, and its role is very significant in the sponge metabolism (Taylor et al. 2007). The sponge produces similar metabolites from their associated bacteria (Radjasa et 
al. 2007), and there is a strong correlation between bacterial richness and secondary metabolites produced by the host (Haygood et al.1999). Since they are filter feeder, the sponge associated bacteria are highly affected by the water quality where the sponges grown. The presence of anthropogenic stressor such as pollutans which is more frequently occured nowadays, might become a burden to the waters and it could affect the bacterial diversity in the sponge and its active metabolite produced.

Aaptamine is a bioactive compound that was once becoming chemotaxonomic marker for sponges of the order Hadromerida where Aaptos sp. is one of this ordo's member. Latest report showed that there are number of species in the ordo Hadromerida producing clinically active compounds in association with microorganism including bacteria (Thomas et al. 2010). Our previous study on the screening of the bioctive compounds from sponges including Aaptos sp from Karimunjawa, Bali, and Lombok, Yogyakarta, Binuangen (Banten) waters found that the aaptamine group compound from the sponge had relatively high yield (Chasanah et al. 2007). Aaptamine-like compounds have also been found in sponges of other genera such as Xestospongia, Suberites, Hymeniacidon, and Luffarriella (Pham et al.2013).

The objective of this research was to analyze the bacterial community associated with Aaptos sp. from two different locations, i.e. Rote Island and Seribu Islands. The two locations represent the less polluted and polluted waters due to human activities.

\section{MATERIAL AND METHODS}

Samples Collection. Aaptos sp. samples were taken by hand using scuba diving equipment from territorial waters at Rote Island (Batu Termanu) Indonesia on May $10^{\text {th }}, 2010$ (geographic location $\mathrm{S} 10^{\circ} 40.228^{\prime} ; \mathrm{E} 123^{\circ} 05.73$ ) and Seribu Islands (Penjaliran Barat) on April 2010, at geographic location of $\mathrm{S} 05^{\circ} 27.720^{\prime}$; E106 $33.603^{\prime}$, at the same depth of $5 \mathrm{~m}$. Three samples of Aaptos sp from each location were mixed for genomic DNA isolation and analyzed to generate the bacterial community profile of the sampels from both locations.

Water $(200 \mathrm{~mL})$ around the Aaptos sp. was collected in triplicates using nansen jar and analyzed on board. Dissolved anorganic nitrogen (nitrate, nitrite, ammonia) and phosphate ions were analyzed by a colorimetric method using HACH DR-890 colorimeter. Salinities and $\mathrm{pH}$ were recorded using refractometer and $\mathrm{pH}$ meter. Dissolved oxygen (DO) and physical characteristics (water temperature, transparancy and water flow) of the waters was conducted in situ using DO meter, thermometer, and Secchi disk, respectively.

Samples Pre-treatment. About $25 \mathrm{~g}$ of Aaptos sp. sample was added into $25 \mathrm{~mL}$ of CTAB extraction buffer, blended, and centrifuged at $200 \mathrm{x}$ g for $2 \mathrm{~min}$. Supernatant was transferred into new microtube and centrifuged at $600 \mathrm{x}$ g for $2 \mathrm{~min}$, the supernatant was subsequently transferred into a microtube sterile and centrifuged at $10000 \mathrm{x}$ g for $5 \mathrm{~min}$.

Genomic DNA Isolation. Genome isolation was conducted following Zhou et al. (1996) with a modification. Pellets which were formed from the pretreatment were homogenized with $750 \mu \mathrm{L}$ CTAB extraction buffer and homogenized for $2 \mathrm{~min}$ at full speed. Samples were then centrifuged at $14000 \mathrm{x}$ g for $30 \mathrm{sec}$, and supernatant were transferred into sterile microtubes, frozen at $-70{ }^{\circ} \mathrm{C}$, and thawed at $65^{\circ} \mathrm{C}$ (this process was done in duplicate). Afterward, samples were placed at room temperature, then, proteinase- $\mathrm{K}$ were added and incubated at $37^{\circ} \mathrm{C}$ for $30 \mathrm{~min}$, and were added with $150 \mu \mathrm{L} 10 \%$ Sarkosyl detergent and incubated at $65{ }^{\circ} \mathrm{C}$ for $30 \mathrm{~min}$. Samples were flipped every $10 \mathrm{~min}$, centrifuged at $10000 \mathrm{x}$ g for $5 \mathrm{~min}$, and the supernatants were transferred into sterile microtubes and added with equal volume of phenol:chloroform:isoamylalcohol (25:24:1), then shaked until well mixed. Samples were then centrifuged at $14000 \mathrm{x}$ g for $5 \mathrm{~min}$., the liquid phase were transferred into sterile microtubes, then equal volume of chloroform were added to the samples and shaked until well mixed. Samples were centrifuged at $14000 \mathrm{x} \mathrm{g}$ for $5 \mathrm{~min}$ and the liquid phase formed was transferred into sterile microtubes and added with $0.6 \mathrm{x}$ volume of cold isopropanol and incubated at $-20{ }^{\circ} \mathrm{C}$ for $20 \mathrm{~min}$. Subsequently the samples were centrifuged at $16000 \mathrm{x}$ g for $5 \mathrm{~min}$. Supernatant were discarded and the pellets formed were washed with $70 \%$ ethanol and then dried. Pellets were homogenized with 50-100 $\mu \mathrm{L}$ Tris-Cl pH 8. Genomic DNA were visualized on 1\% agarose in $1 \times$ TAE buffer, which were visualized with cyber-gold. DNA genomes were purified using DNA Wizard Genomic DNA Purification Kit ${ }^{\circledR}$ (Promega).

16S rRNA Gene Amplification and T-RFLP Analyses.16S-rRNA gene was amplified using Bio-Rad C-1000 with universal primers 27F-FAM (5'-AGA GTTTGATCCTGGCTCAG- 3') which was labeled at the 5'-end with the phosphoramiditefluorochrome 5carboxyfluorescein (FAM) and 1387R (5'-GGGCGG WGTGTACAAGGC-3') (Marchesi et al. 1998). To 
perform gene encoding $16 \mathrm{~S}$ rRNA PCR, master mix was made with the following composition: $12.5 \mu \mathrm{LGoTaq}$ (Promega, Madison, WI, USA), $1 \mu \mathrm{L}$ primer $27 \mathrm{~F}$ and 1387R primers ( 25 pmol $\left.\mu \mathrm{L}^{-1}\right), 9.5 \mu \mathrm{L} \mathrm{ddH}_{2} \mathrm{O}$, and $1 \mu \mathrm{L}$ of the DNA genome as template. PCR was performed at $95^{\circ} \mathrm{C}$ for $5 \mathrm{~min}, 30$ cycles of $95^{\circ} \mathrm{C}$ for $30 \mathrm{sec}, 55^{\circ} \mathrm{C}$ for $30 \mathrm{sec}$, and $72{ }^{\circ} \mathrm{C}$ for $1 \mathrm{~min}$, followed by $72{ }^{\circ} \mathrm{C}$ for 10 min. PCR products were visualized on $1 \%$ agarose gel in 1x TAE buffer. The 16S rDNA was then purified using QIA quick PCR Purification Kit (Qiagen, Germany) according to the manufacturer's protocol.

T-RFLP analysis was conducted as follow: Fluorescently labeled PCR products were single digested with 3 endonuclease enzymes namely $B s h$ 1236I, RsaI, and $\mathrm{HpaII}$ for $24 \mathrm{~h}$ at $37^{\circ} \mathrm{C}$. Digestion was performed in a total volume of $20 \mu \mathrm{L}$ containing $2 \mu \mathrm{L}$ restriction enzymes, $2 \mu \mathrm{L}$ of $10 \mathrm{x}$ restriction buffer, and $16 \mu \mathrm{L}$ of PCR products. Digestion products were purified using EDTA-NaOAc precipitation method (Sambrook and Russel 2001). Pellet of the digested products were mixed with $12 \mu \mathrm{L}$ deionized formamide and $0.5 \mu \mathrm{L}$ of internal size standard (ROX-500, Applied Biosystems, Foster City, CA, USA). This mixture was denatured for $5 \mathrm{~min}$ at $95^{\circ} \mathrm{C}$ and immediately chilled on ice before electrophoresis on an ABI PRISM 310 genetic analyzer (Applied Biosystem, Foster City, CA, USA) operated in GeneScan. After electrophoresis, the length of fluorescently labeled TRFs was determined by comparison with internal standards by using GeneScan software (Applied Biosystems, Foster City, CA, USA). Fragment sizes were analyzed using FragSort ver.5.0 software (www.oardc.ohiostate.edu/trflpfragsort/index.php) with data base from Microbial Community Analysis (Shyu et al. 2007).

To evaluate richness and evenness, diversity statistics were calculated from each population. Population richness (S) was total number of distinct population. Diversity Index Analysis was analyzed using Shannon-Wiener Index (H), Simpson's Index (D), and Evenness (E). The Shannon-Wiener diversity index was calculated from equation $\mathrm{H}=-\Sigma(\mathrm{pi})(\ln \mathrm{pi})$ and the Simpson's Index was calculated from equation $\mathrm{D}=1-((\Sigma$ ni (ni-1) / N (N-1)). Evenness value was calculated from equation $\mathrm{E}=\mathrm{H} / \mathrm{H}_{\max }, \mathrm{H}_{\max }=\ln \mathrm{S}$ (Allen et al. 2009).

Analysis of Aaptamine and Isoaaptamine. For analysis of aaptamine and isoaaptamine, triplicates of $5 \mathrm{~g}$ wet weight of frozen Aaptos sp. were extracted using 10 $\mathrm{mL}$ of methanol (pa), and centrifuged to coagulate suspended solid. The supernatan were concentrated with nitrogen and freezed dried, and redissolved in methanol providing concentration of $10 \mathrm{mg} \mathrm{mL}^{-1}$. Concentrated supernatants $(5 \mu \mathrm{L})$ was injected into HPLC system Shimadzu 10-AD with PDA detector and Shimpack VP ODS coloumn $(2.0 \mathrm{~mm} \times 150 \mathrm{~mm})$. Eluent used was $20 \%$ acetonitrite $/ \mathrm{H}_{2} \mathrm{O}(1 \% \mathrm{TFA})$ at a flow rate $0.2 \mathrm{~mL}$ $\mathrm{min}^{-1}$. Concentration of aaptamine and isoaaptamine were determined according to Dewi et al. (2012) as average of triplicate samples.

\section{RESULT}

Bacterial community profiles and its electropherograms observed from Aaptos sp. from two sampling areas of Rote Island and Seribu Islands can be seen at Fig 1 and Fig 2. Aaptos harvested from Rote island contained more diverse bacteria than those of Seribu Islands as shown in Table 1, using Shannon-Wiener index, i.e. the $\mathrm{H}$ value for Rote and Seribu Islands was 5.53 and 4.78 , respectively. This was supported by Simpson's Index, in which the D value of the bacterial population from Aaptos sp. from Rote Island (0.894) was higher than that of Seribu Islands (0.884). Based on the calculation of Evenness value (E), the distribution of the bacteria population from Aaptos sp. In Rote Island (0.653) was more highly distributed than that of Seribu Islands (0.676). The higher $\mathrm{D}$ values the higher the diversity, and the bigger $\mathrm{E}$ values the lower in variation distribution of bacterial community.

There were 24 main classes and 1985 microorganisms of bacterial population identified along with uncultured microorganisms, uncultured organisms, uncultured bacteria, and unidentified organisms detected from Aaptos sp. from Seribu Islands, while Aaptos sp. from Rote Island which was considered richer had a total of 6128 microorganisms. Sponges from both locations shared $40.81 \%$ similarity of bacterial community, and were dominated by the same classes, i.e. Actinobacteria, Bacilli, Bacteroidia, Deinococci, $\alpha$-Proteobacteria, $\delta$ Proteobacteria, and $\gamma$-Proteobacteria. Clostridia was the only class which was found in sponge sample from Seribu Islands but was not found in those from Rote Island. On the contrary, there were 10 classes that were found in sponge from Rote Island but were not found in those from Seribu Islands.

Water quality analysis was conducted in the sampling areas at the same time of sampling (Table 2). Analysis of the bioactive compounds, i.e. aaptamine and isoaaptamine, was only carried out with samples from Seribu Islands but it could not be conducted with those from Rote Island due to the technical problem of sample storage. The Aaptos sp. from Seribu Islands contained $2.197 \%$ of aaptamine and $0.578 \%$ of 
isoaaptamine (dried extract weight).

\section{DISCUSSIONS}

T-RFLP method has been used in this study since compared to those of Seribu Islands. Low water flow in Seribu Islands might cause no much change of the inhabitants (bacteria) in the Aaptos including Clostridia from this area.

High value of phosphate in Rote Island could

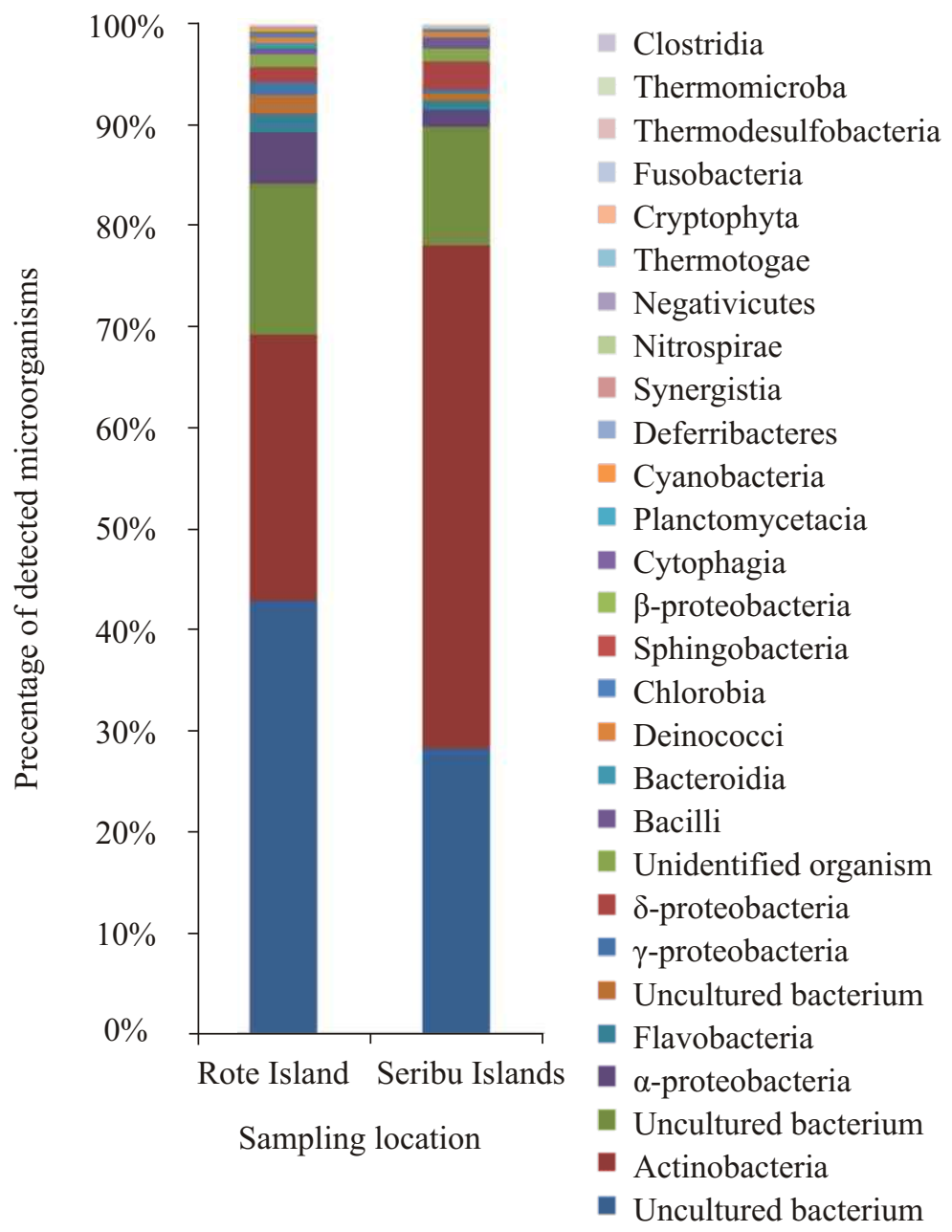

Fig 1 Percentage of detected microorganisms in Aaptos sp. collected from Rote Island and Seribu Islands.

this method was reported to be effective in determining bacterial communities in a range of environments, highly reproducible, rapid, and amenable to field-scale experiments (Liu et al.1997; Dunbar et al. 2000). The diversity of bacterial communities associated with Aaptos sp. in both sampling sites showed that the bacterial community structures were different eventhough dominated by similar bacteria. Based on the water quality (Table 2), Rote Island waters showed higher water flow, indicating that the water in that location was more circulated, and this would affect the bacteria in the sponge as filter feeder organism. Stronger water flow in Rote Island waters might lead to frequent water exchange that enters the sponge body, and this might be the reason why Aaptos sp. from Rote Island waters contained more diverse micoorganisms indicate there was domestic contaminations from human activity such as sewage containing detergent or it might be an accumulation of phosphate ion from rock decay in the marine waters that might be affected by high water flow in the waters. This contamination might be indicated by the presence of phosphate degrading bacteria such as Bacilli which was detected in more quantity in the sponge from Rote Island (Fig 1). Those bacteria could produce phophatase enzyme which plays a key role in mineralizing organic phosphate into inorganic phosphate.

From the data, it can be seen that water quality of Rote Island was better than Seribu Islands waters. Ammonia content of Seribu Islands waters depicted that the waters was highly polluted with domestic waste. The $\mathrm{pH}$ value of Seribu Islands waters which 

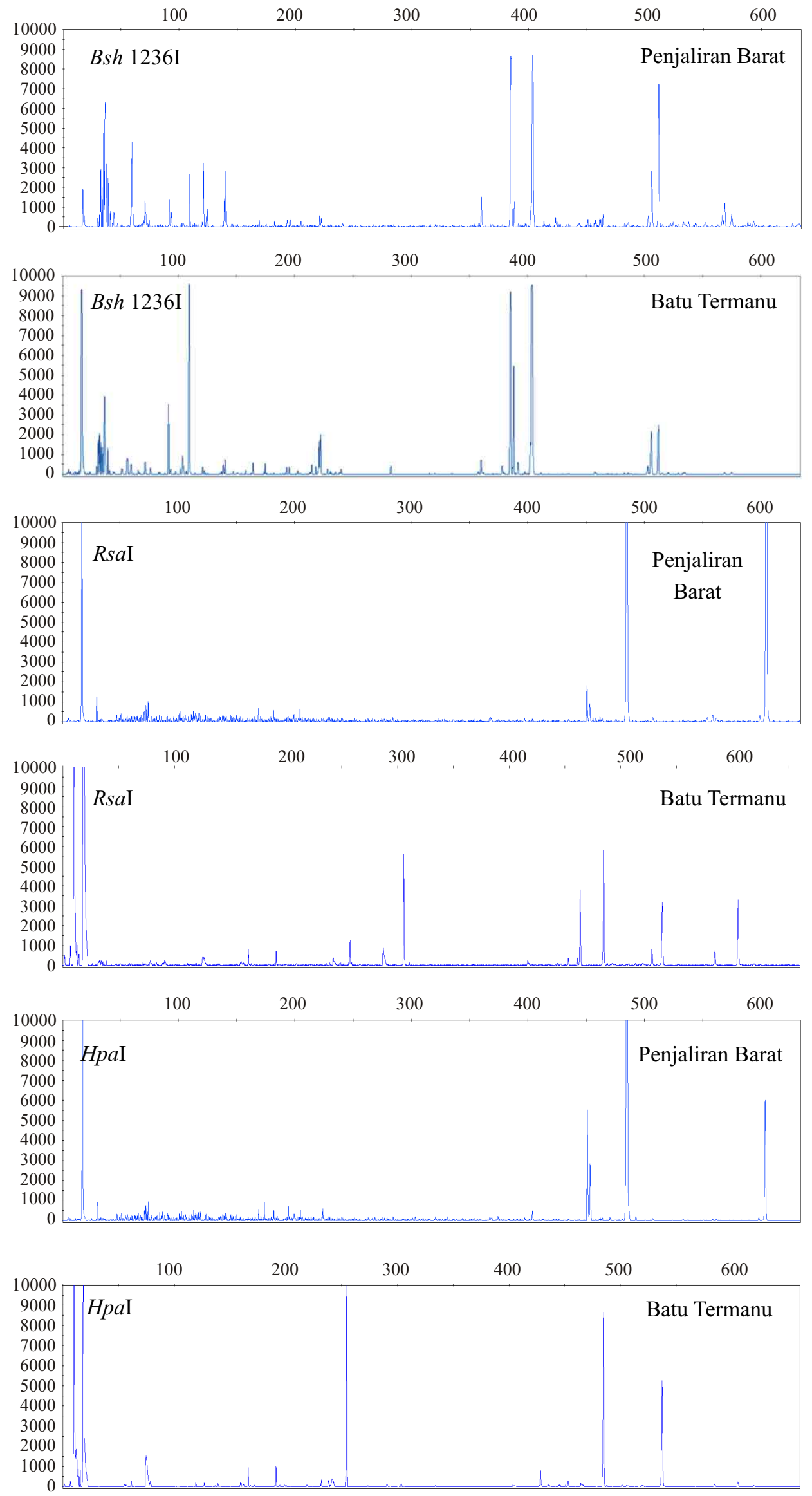

Fig 2 Electropherograms of bacterial community T-RFLPs generated from rDNAs with a labeled reverse primer and 3 endonuclease digest namely Bsh 1236I, RsaI, and HpaII obtained from representative water samples from Penjalinan Barat (Seribu Islands) and Batu Termanu (Rote Island) waters. 
Table 1 The diversity index of bacterial community associated with Aaptos sp.

\begin{tabular}{lcc}
\hline & Rote Island & Seribu Islands \\
\hline $\mathrm{H}_{\max }$ & 5.533 & 4.787 \\
$\mathrm{H}$ & 3.611 & 3.235 \\
$\mathrm{D}$ & 0.894 & 0.884 \\
$\mathrm{E}$ & 0.653 & 0.676 \\
\hline
\end{tabular}

D: Simpson's index; E: Evenness; H: Shannon-Wiener index; $\mathrm{H}_{\max }$ : $\ln$ population richness

Table 2 Water quality of Rote Island and Seribu Islands

\begin{tabular}{lccccccccc}
\hline & $\begin{array}{c}\text { Water } \\
\text { flow } \\
(\mathrm{m} / \mathrm{sec})\end{array}$ & $\begin{array}{c}\text { Temperature } \\
\left({ }^{\circ} \mathrm{C}\right)\end{array}$ & $\begin{array}{c}\text { Salinity } \\
(\%)\end{array}$ & $\mathrm{pH}$ & $\mathrm{DO}$ & $\begin{array}{c}\text { Phosphate } \\
(\mathrm{ppm})\end{array}$ & $\begin{array}{c}\text { Nitrate } \\
(\mathrm{ppm})\end{array}$ & $\begin{array}{c}\text { Nitrite } \\
(\mathrm{ppm})\end{array}$ & $\begin{array}{c}\text { Ammonia } \\
(\mathrm{ppm})\end{array}$ \\
\hline $\begin{array}{l}\text { Rote } \\
\text { Island }\end{array}$ & 0.23 & 31 & 33.33 & 8.1 & 6.83 & 0.533 & 0.050 & 0.002 & 0.033 \\
$\begin{array}{l}\text { Seribu } \\
\text { Islands }\end{array}$ & 0.09 & 32 & 31.00 & 7.7 & 6.73 & 0.017 & 0.067 & 0.000 & 0.100 \\
\hline
\end{tabular}

was below the $\mathrm{pH}$ required for corals growth (7.8-8.8) (Jameson and Kelty 2004) suggested that an acid contamination might be occured in the waters. Low water flow in Seribu Islands waters also causes the pollutants stay longer in the waters, therefore it affects the living microorganisms and marine biota in the waters. Previous work showed that water quality has affected the metabolite richness of the Nephthea spp harvested from numbers of sampling point at Alor waters (Januar et al. 2012).

Aaptos sp. tissue from both locations were dominated by the same bacteria, but different in quantity. The dominant bacteria from both samples were Actinobacteria, Proteobacteria, and Flavobacteria. Class Actinobacteria was very abundant in Aaptos sp harvested from Seribu Islands i.e. 50\% compared to $26 \%$ of Rote Island waters. Seribu Island was consider more polluted than Rote Island waters.

On the other hand, class Proteobacteria was found more likely higher in Rote Island waters compared to that of Seribu Islands waters. Actinobacteria was reported to be the most morphologically diverse prokaryotes, and are widely distributed in both terrestrial and aquatic ecosystems (Servin et al. 2008). One of the well studied Actinobacteria species is Streptomyces sp. Metabolite compounds produced by Streptomyces sp. was reported could exhibit cytotoxic activity against cancer cell lines (Chasanah et al. 2009;
Khan et al. 2010). Study conducted by Suthindhiran and Kanabiran (2010) also reported that marine Actinomycetes was very potential in producing the active metabolites. Streptomyces has been used for commercial production of different compounds for various therapeutic agents such as tetracycline as antibacteria, amphotericin as antifungal, and tacrolimusas immunosuppressant (Suthindhiran and Kannabiran 2010).

Another dominating class was Proteobacteria $(\alpha, \beta$, $\delta$, and $\gamma$-proteobacteria) which was found more abundant in Aaptos sp. from Rote Island, i.e. about 7\% compared to $4 \%$ in Aaptos sp. from Seribu Islands waters. Li et al. (2006) reported that Proteobacteria are common in marine environment and might be used as a biomarker on sponge host. Proteobacteria have been suggested to have varied effects on sponge hosts such as nitrogen fixation. Proteobacteria especially $\gamma$ proteobacteria has been reported to produce the most chemically diverse bioactive natural products such as agrochelin, a cytotoxic thiazole alkaloid from Agrobacterium and B-90063, a dimericoxazolepyridone analog from Blastobacter, which indicates the biomedical potential of this class of Proteobacteria. In addition, an early investigation of the $\alpha$-proteobacterium Thalassospira sp. strain CNJ328, resulted in the discovery of unique immunosuppressive peptides, thalassospiramides A and $\mathrm{B}$ ( $\mathrm{Oh}$ et al. 2007). 
Kalinovskaya et al. (2004) reported that Proteobacteria could produce low molecular-weight biological active compounds with antimicrobial and surface-active properties. Another research by Radjasa et al. (2007) reported that metabolites of Proteobacteria which was isolated from Aaptos sp. from Panjang Island, Jepara, were active against multi drugs resistant strains of microorganism. All of the above studies indicated that there is correlation of sponge bioactive compounds with Proteobacteria and/or Actinobacteria, which were dominant microorganism in Aaptos sp. used in this study. Sponge from ordo Suberitidae where Aaptos sp. is one of the member was reported to produce therapeutic important bioactive compounds of microbial origin. Alpha, $\beta, \gamma, \delta$-Proteobacteria, and Actinobacteria has been reported to be possible contributors of pharmacologically relevant secondary metabolites of sponges, in addition to Firmicutes, Cyanobacteria, and Fungi (Thomas et al. 2010).

In this study, the bioactive compounds, i.e. aaptamine and isoaaptamine have been extracted from the Aaptos sp. tissue from Seribu Islands, but we failed to extract those from sample from Rote island waters due to the failure of the sample storage. Aaptamine in the Aaptos sp. tissue harvested from Seribu Islands was $2.197 \%$ and isoaaptamine was $0.578 \%$ (dried extract weight). Since the same compounds from Rote samples could not be analyzed, we could not compare both samples.

To conclude, the structure of bacterial community in the Aaptos sp. harvested from Seribu Islands and Rote Island waters was affected by water quality, but in this study, we can not yet correlate the bacterial community with the bioactive content of the sponge, i.e. aaptamine and isoaaptamine. Bacterial community associated with Aaptos sp. from Rote Island which was less polluted and having higher water flow, was more diverse and highly distributed than that of Seribu Islands. However, they both shared $40.81 \%$ similarity of microorganism, from which they had the same dominant bacteria, i.e. Actinobacteria and Proteobacteria that are well known as bioactive producer.

\section{REFERENCES}

Allen B, Kon M,Yaneer BY. 2009. A new phylogenetic diversity measure generalizing the shannon index and its application to phyllostomid bats. Am Nat. 174(2). doi:10.1086/600101

Chasanah E, Januar HI, Irianto HE, Bourne D, Liptrot C, Wight A. 2009. Screening of anticancer activity of fungi derived from indonesian marine sponge. J Marine
Fisheries Postharvest Biotechnol special edition:1-7.

Chasanah E, Januar HI, Wright AD. 2007. Activity Completion Report. Public Sector Linkages Program (PSLP). ABN 78961616230.

Coutinho AF, Chanas B, Souza TML, Frugrulhetti ICPP, Epifanio RA. 2002. Anti HSV-1 alkaloids from a feeding deterrent marine sponge of the genus Aaptos. Heterocycles 57(7):1256-1272.

Dewi AS, Hadi TA, Januar HI, Pratitis A, Chasanah E. 2012. Study on the effect of pollutants on the production of aaptamine and the cytotoxicity of crude extract from Aaptos suberitoides. Squalen 7(3):97-104.

Dunbar J, Ticknor LO, Kuske1 CR. 2000. Assessment of microbial diversity in four southwestern United States soils by $16 \mathrm{~S}$ rRNA gene terminal restriction fragment analysis. Appl Environ Microbiol. 66(7):2943-2950.

Gul W, Hammond N, Yousaf M, Bowling J, Schinazi R, Wirtz, S, de Castro AG, Cuevas C, Hamann M. 2006. Modification at the $\mathrm{C} 9$ position of the marine natural product isoaaptamine and the impact on HIV-1, mycobacterial, and tumor cell activity. Bioorg Med Chem. 14(24):8495-8505. doi:10.1016/j.bmc.2006.08.042.

Haygood MG, Schmidt EW, Davidson SK, Faulkner DJ. 1999. Microbial symbionts of marine invetebrates: Opportunities for microbial biotecnology. Mol Microbiol Biotechnol. 1(1):33-43.

Jameson SC, Kelty RA. 2004. A review of indikatorsfo land-based pollution stress on coral reefs, A background paper for joint EPA/NOAA/USGA/DOI workshop on Assessing Pollution Stress on Coral Reefs; 2004, August 31-September 2, Honolulu, Hawaii (USA).

Januar HI, Marraskuranto E, Patantis G, Chasanah E. 2012. LC-MS metabolomic analysis of environmental stressor impacts on the metabolite diversity in Nephthea spp. Chronicles of Young Scientists 3(1):5762. doi:10.4103/2229-5186.94319.

Kalinovskaya NI, Ivanova EP, Alexeeva YV, Gorshkova NM, Kuznetsova TA, Dmitrenok AS, Nicolau DV. 2004. Low molecular-weight, biologically active compounds from marine pseudoalteromonas species. Curr Microbiol. 48(6): 441-446.

Khan ST, Komaki H, Motohashi K, Kozone I, Mukai A, Takagi M, Shin-Ya K. 2010. Streptomyces associated with a marine sponge Haliclona sp; biosynthetic genes for secondary metabolites and products. Environ Microbiol.13(2):391403. doi:10.1111/j.1462-2920.2010.02337.x.

Li ZY, He LM, Wu J, Jiang Q. 2006. Bacterial community diversity associated with four marine sponges from the South China Sea based on 16S rDNA-DGGE fingerprinting. J Exp Marine Biol Ecol. 329(1):75-85. doi:10.1016/j.jembe.2005.08.014.

Liu WT, Marsh TL, Cheng H, Forney LJ. 1997. Characterization of microbial diversity by determining terminal restriction fragment length polymorphisms of genes encoding 16S rRNA. Appl Environ Microbiol. 63(11):4516-4522.

Marchesi JR, Sato T, Weightman AJ, MartinTA, Fry JC, Hiom SJ, Wade WG. 1998. Design and evaluation of 
useful bacterium-specific PCR primers that amplify genes coding for bacterial 16S RNA. Appl Environ Microbiol. 64(2):795-799.

Oh DC, Strangman WK, Kauffman CA, JensenPR, Fenical W. 2007. Thalassospiramides A and B, immunosuppressive peptides from the marine bacterium Thalassospira sp. Org Lett. 9(8):1525-1528. doi:10.1021/ol070294u.

Pham CD, Hartmann R, Müller WEG, Voogd N, Lai D, Proksch P. 2013. Aaptamine Derivatives from the Indonesian Sponge Aaptossuberitoides. J Nat Prod. 76(1):103-106. doi:10.1021/np300794b.

Rachmat R, Murniasih T. 2001. Identifikasi senyawa sterol dari spons Aaptos sp. asal spermonde [Identification of sterol of Aaptos sp. from spermonde]. Prosiding Seminar Nasional IV Kimia dalam Pembangunan; Hotel Santika Yogyakarta, 2001. 27-28 Mar. Jaringan Kerjasama Kimia Indonesia. Yogyakarta(ID). p 89-92.

Radjasa OK, Kencana DS, Sabdono A, Hutagalung RA, Lestari ES. 2007. Antibacterial of marine bacteria associated with sponge Aaptos sp. against multi drugs resistant (MDR) strains. J Matematika Sains. 12(4):147-152.

Sambrook J, Rusell DW. 2001. Molecular Cloning: A Laboratory Manual. $3^{\text {rd }}$ edition. Cold Spring Harbor (NY): Cold Spring Harbor Laboratory Press.
Servin JA, Herbold CW, Skophammer RG, Lake JA. 2008. Evidence excluding the root of the tree of life from the Actinobacteria. Mol Biol Evol. 25(1):1-4. doi: $10.1093 / \mathrm{molbev} / \mathrm{msm} 249$.

Suthindhiran K, Kannabiran K. 2010. Diversity and exploration of bioactive marine actinomycetes in the Bay of Bengal of the Puducherry coast of India. Ind J Microbiol. 50(1):76-82. doi:10.1007/s12088-0100048-3.

Shyu C, Soule T, Bent SJ, Foster JA, Forney LJ. 2007. MiCA: A Web-based tool for the aof microbial communities based on terminal-restriction fragment length polymorphisms of $16 \mathrm{~S}$ and $18 \mathrm{~S}$ rRNA genes. J Microb Ecol. 53(4):562-570. doi:10.1007/s00248-0069106-0.

Taylor MW, Radax R, Steger D, Wagner M. 2007. Spongeassociated microorganisms: Evolution, ecology and biotechnological potential. Microbiol Mol Biol Rev. 71(2):295-347. doi:10.1128/MMBR.00040-06.

Thomas TRA, Kavlekar DP, Loka Bharathi PA. 2010. Marine drugs from sponge-microbe association-a review. Mar Drugs. 8(4):1417-1468. doi:10.3390/md8041417.

Zhou J, Bruns MA, Tiedje JM. 1996. DNA recovery from soils of diverse composition. Appl Environ Microbiol. 62(2):316-322. 